\title{
The Ability of Health Organizations to Change - Why do Change Need a Process and Project Approach?
}

\author{
Joanna Jasińska* \\ Warsaw Medical University named Tadeusz Kozluk, Poland
}

*Corresponding author: Joanna Jasińska, MBA, prof. Warsaw Medical University named Tadeusz Kozluk, Vice-Rector for Education and Development, Warsaw, Poland.

\begin{abstract}
The aim of the article is both an attempt to identify the relationship between various disciplines of management sciences (change management, process management, project management) and a reference to the issue of their application and integration in healthcare organizations. It seems that this is a serious problem in the context of the inevitability of making changes in medical organizations, especially in the face of an ongoing pandemic (in a relatively short time). In addition, the ever-increasing complexity of healthcare organizations, while the pace of technological innovation in medicine. The article is a review - it integrates and interprets the current state of knowledge in the field of change management, process management and project management, indicating the need and possibilities of integration and symbiosis of various management subdisciplines. It was developed primarily using critical literature analysis.

Keywords: change management, change management in healthcare organizations, process management, project management, integrated management sub-disciplines
\end{abstract}

\section{Introduction}

Due to the increase in the complexity of the healthcare organization itself and the environment in which they operate, there has been a need to divide tasks and specializations in relation to management. This results in a tendency to separate individual management sub-disciplines (both in theoretical and practical sense), focusing on a specific aspect / scope of the organization's operation. It certainly allows for a more complete consideration of the specifics of a given aspect of the organization's functioning, a more adequate selection of management tools ensuring the efficiency of operation of individual elements of the organization, but at the same time there is a lack of a holistic view of the organization (in the spatial, temporal, subject, subjective sense). All shortcomings related to the deepening of specialization in the management of selected ranges of activities of medical organizations are also revealed.

It is therefore worth at least once in a while to attempt to assess the advancement in the development of individual management subdisciplines, but also to attempt to assess their compatibility, identify possible desirable and undesirable effects of this state of affairs for the entire organization and the possibilities of fuller integration and related conditions.

\section{The Ability of Healthcare Organizations to Change}

Conditions in which health care organizations operate today, i.e. globalization, hypercompetition, virtualization, technology development, shortening organization life cycle, dissemination of 
network structures, dynamics of patient expectations, rising costs of medical services, rising costs of highly specialized procedures, rising costs of medicines and others, make it increasingly difficult for the organization to maintain a balance between stability and the need to make changes. What's more, in order to achieve the natural goal of the organization's persistence, it must constantly make changes, because the changes have become a kind of "guarantor" of survival and the opportunity to face the challenges of the future [1]

Until recently, the frequency of changes and their degree of radicality were definitely lower; currently we are dealing with a marked acceleration of the pace of change and an increase in the demand for more complex changes (cross-sectional, fundamental), for example regarding the business model of operation (changes consisting in introducing product innovations are insufficient). This situation confronts the organization with the need to deal with many interdependent changes (related to each other or mutually conditioning) or with independent changes (running side by side at the same time in parallel). Today, it seems obvious that a modern organization must shape and maintain an appropriate level of ability to change, i.e. have a specific potential for variability that ensures its adaptation to the transforming operating conditions, and at the same time determines maintaining its appropriate competitive position on the market, thus enabling it to achieve satisfactory level of efficiency in action.

In the inevitable process of its change (making many different changes in parallel), there is a problem of rational management of the ability to change, which translates into the selection of the right changes (according to the appropriate selection criteria), setting priorities in the schedule of their course, etc., so that the organization can, by adapting to changing operating conditions, maintain flexibility as an intermediate state between rigidity and unmanageable variability (chaos). During changes in health care organizations, various types of problems are revealed, including "Over-reactivity" of the organization, leading to initiating too many changes at the same time, activating the potential of variability at the wrong time (too late or prematurely), engaging the ability to change in changes that do not give the expected results. This can lead to a waste of organizational change potential. Therefore, due to the fact that changing medical organizations is inevitable, but it also exposes the organization to destabilization, then there is a need to manage changes in the organization. This need results from the fact that the change is essentially the source of the organization's "elixir of life", which is reflected in the current management paradigm Harasim [2].

Without going deeper into the discussion about management paradigms and related controversies, it can be noted that individual authors agree that the unavoidable in formulating standards supporting the management of health care organization is the paradigm of changing environment and the need to deal with the ongoing uncertainty of these changes Penc [3]. J. Moczydłowska [4] calls it the paradigm of turbulence of the environment. P. F. Drucker [5] notes that this variability forces management of the 21st century organization to orientate itself primarily outside the organization and define its goals in the context of market and customer needs, which does not preclude changes in organizations whose impulses have their source inside organization.

Considering that management paradigms are of a temporary nature Jamali [6], they are losing their current validity, while new ones appear - we are dealing here with a kind of symbiosis of paradigms that structure a certain system. According to B. WoźniakSobczak [7], the metaparadigms in this system is the turbulence of the environment, i.e. dynamic states of reality being the result of trends and features of modern economy (the next levels are: the overall paradigm referred to e.g. network organization and partial paradigms related to e.g. to resources, relationships, technologies in the organization). According to W.M. Grudzewski and I.K. Hejduk [8] such metaparadigms is sustainability, which they define as "the ability to constantly learn, adapt and develop, revitalization, reconstruction, reorientation to maintain a stable and outstanding market position ...", emphasizing that for such of the essence of "sustainability" understood is the assumption of high dynamics of change. Considering the fact that the meta-paradigm of the dynamic reality of health care organizations, meets the requirement of scientific consideration as much as possible (which makes it impossible to question it) [9]. In addition, there are no indications that we are able to free ourselves from the current paradigm (in a way we are its victims [10]. One can formulate the thesis that in the foreseeable future this change will make sense to the management of health care organizations, understood here as an action oriented on achieving the goals of medical organizations. Thanks to this, it ensures its effectiveness and efficiency. The ability to change, both in the sense of adapting to changed operating conditions and in the sense of initiating changes on the principle of anticipation, i.e. seizing the opportunity, realizing the vision, will be a condition for the functioning of the organization (both in terms of duration and development).

Shaping the ability to change as the subject of change management determines the ability of the organization to change in its environment and inside while maintaining stability, which is necessary to maintain the continuity of the organization in turbulence [11]. Making changes in response to environmental impulses or internal needs is realized by a wide (constantly expanding) spectrum of concepts, approaches and management tools - they also include process management and project management. To what extent, therefore, the implementation of changes in the organization of health care as the implementation of a metaparadigms in management requires a process approach (management), to what extent project management contributes to the implementation of changes in the organization, in what 
relations these management subdisciplines remain, what are the chances of their fuller integration?

\section{Process Management and Change Management in the Organization}

A review of the subject literature on organization management indicates the possibility of using various approaches, including functional, structural, process and design. Considering the criterion of striving for efficiency (as an imperative of action inscribed in the organization), it should be noted that since 2-3 decades, the "exhaustion" of the functional approach possibilities and the call for a wider dissemination of the process approach are increasingly emphasized. The potential benefits of this change are usually presented on the basis of combining features and features of a functional and process approach $[12,13]$. Growing interest in the process approach in practice has been to some extent forced by the introduction of quality assurance standards, although favoring process management is clearly associated with the benefits that make up the so-called the result of the organization's reconstruction, it is its transition from functioning in a static structure, primarily oriented on functions, to a dynamic structure in which process orientation dominates. This effect, in the form of a noticeable improvement in operational efficiency and increase in efficiency, is associated with specific features of a process-oriented organization These features are much more likely to be conducive to achieving efficiency improvements in current operating conditions, far from being stable.

Successful structural reorientation leads to the construction of a process organization, which, according to P. Grajewski [14] is characterized by the following attributes:

a. is a system that directs relations between the implementers of its tasks to activities contained in designed processes; all organizationally separated areas are treated equally due to their usefulness in the implementation of internal orders;

b. each area of the organization has the option to choose to perform the contract both inside and outside the organization; each area of the organization is an internal service provider and can localize its services in the internal or external market (unless otherwise noted);

c. separate areas have the option of negotiating the terms of service delivery, within a specific chain of procedures for creating and implementing medical procedures, which involves mastering the ability to determine their costs.

d. This means introducing market relations inside the organization and taking advantage of the opportunity to open more fully to the market environment. In addition, verification of the actual participation of individual elements of a medical organization in creating added value, and this mainly determines the possibilities of improving the efficiency and competitiveness of healthcare organizations. e. Another change in the organization of health care towards processes Grajewski [14]:

f. the process approach somewhat makes it easier to improve the operation of the system of medical organizations. First of all, thanks to the fact that it is characterized by structuring tasks and procedures;

g. the process approach emphasizes the focus on the patient's focus and the patient's needs. This is reflected in the way medical processes and procedures are designed;

h. the process approach directs the activities of organization members to explore the broader spectrum of fulfillment in achieving goals than in the functional system, which is an impulse supporting the learning of both its members and the organization itself.

i. Supporters of the process approach emphasize that such an organization creates conditions for:

j. introducing changes in individual processes as well as in their configurations on the principle of eliminating old and introducing new procedures;

k. maintaining an optimal pace of change in the face of the need to adapt to increasing pressure on change.

Assuming that the measure of evaluation of activities within process structures is the effectiveness of health care organization and patient satisfaction, it is practically unrealistic to ignore the appearance of specific reasons for change. Especially if they relate to changes closing within the boundaries of a given process. In such a situation, such features of the process structure as the ability to work in a team based on trust, despite being formalized, will be used automatically. In addition, communication and information flow, validation to operate throughout the entire process. Similarly, at the stage of implementation (freezing change) as part of a process-oriented structure - the natural integration of various process components at the level of goal, activities, information flow and other resources of cooperating participants. The process seems to be particularly favorable for consolidating the changes introduced. A community of goals, holistic thinking (not through the prism of narrow specialization), a wider scope of responsibility and decision-making powers, as well as the possibility of a flexible approach to managing the capital of medical workers are potentially minimizing the cessation or possible retreat from initiated changes in health care organizations.

Assuming that the essence of managing change in healthcare organizations comes down to implementing the cycle of achieving the organization's goals, which can mean looking for ways and means to implement them. It may also be possible to explain the relationship between the goal and change in a relatively simple way [15]. Therefore, when indicating further goals, as well as when analyzing them, one should take into account the necessity 
of introducing changes and launching subsequent change processes [16,11]. Perhaps it also initiates the implementation of proper processes (main, auxiliary, management) in healthcare organizations. On the other hand, the goals of healthcare organizations are the link between changes and processes in these organizations [17].

Considering the relationship between management and process approach and change management in healthcare organization, one should also take into account the diverse spectrum of tasks carried out as part of process management. R Paim HM. Caulliraux R Cardoso [18]. Analyzing process management tasks in a conceptual and practical dimension, the following groups of tasks can be distinguished:

- designing processes and procedures,

- $\quad$ operational process management,

- $\quad$ supporting learning processes.

The tasks of the first group are mainly associated with creating conditions for introducing cross-sectional, revolutionary changes that usually violate the current procedure. They become a requirement to obtain and maintain a competitive advantage. The significance of these changes does not allow decisions to be made at the level of the owners of individual processes (or the management of functional departments), institutional and procedural solutions are needed to ensure extended coordination. Those that give you the opportunity to make use of diverse and specialized knowledge and skills from specialized entities within specific ranges and functions.

The tasks of the second group are the focus of process management. They focus on each time and repetitive implementation of tasks that do not violate the current architecture of processes and procedures in the organization of health care. They assume the introduction of not very large modifications and improvements, which through their systematic implementation are able to significantly improve the advancement in a medical process organization. Thus, creating conditions for further improvement of the organizational effectiveness. Considering that the use of continuous process improvement over time leads to a critical point. What is due to the fact that further improvements are not able to bring the expected and desired results, in the literature on the subject [Hofman] it is recommended to use a mixed approach. A mixed approach, i.e. alternate implementation of radical changes and continuous improvement of processes. This approach assumes that the process implementers together with its owner initiate and request and introduce changes in the process and processes. It is important here to support activities related to creating conditions for learning, releasing creativity, and deliberate involvement of organization participants in this type of undertaking. Contemporary process management, including a group of tasks related to supporting organizational learning, becomes a means to more fully achieve the objectives of health care organization.

Recognizing the compatibility of change management, which is based on the idea of organization learning and process management, it should be noted, however, that the nature of a process organization does not directly indicate that:

- $\quad$ the process approach had a mechanism for optimizing the changes introduced and made in the organization,

- $\quad$ reduced the risk and costs associated with changes,

- $\quad$ triggered "defense mechanisms" against the need to make changes that were not always justified or under "overload" changes. And thus, it ensured the functioning of health care organizations in relatively stable conditions.

\section{Coupling Project Management with Change Management}

In the process approach, the category of goal as a desired state in the future appears against the backdrop of harmonizing activities. Is the main focus of process management. On the other hand, in project management, achieving a goal or goals is oriented towards achieving a designated result, which is particularly emphasized and results from the nature of project management [19]. In addition, it indicates the relationship between change management and project management.

As noted by E. Sońta-Drączkowska [20], the projects are a response to the need to implement various changes in a healthcare organization. They can be treated as "carriers" of these changes. M. Trocki [Trocki (ed.), considering the structure of activities implemented by a medical organization in the light of two criteria, i.e. complexity and repeatability, draws attention to the special role of projects [21-24]. And also on their growing participation in the implementation of all activities. Stressing that the need for project management is based on necessity on the one hand, and on the other, the potential benefits of focusing on projects on the other. It can be assumed that project management is an expression of an attempt to standardize those activities in healthcare organizations that are unique, individualized. And each time they lead to results clearly indicating the difference between the initial state and the final state $[25,26]$.

Project and change management is confirmed, among others, in:

- $\quad$ similarity of changes to the project life cycle. It includes the following stages: idea, planning, implementation and closure,

- relying on a team collaboration formula,

- $\quad$ having a strictly defined amount of resources and means to achieve the objectives,

- $\quad$ the course of activities within the prescribed time frame. Medical procedures have a definite beginning and end, 
- the need to manage many changes simultaneously.

The design approach is able to meet the needs of health care organizations for changes. It provides flexibility in adapting to dynamic operating conditions and the growing number of reasons for introducing changes. Considering that the changes may have their source in systematically prepared plans and in dynamically changing situations on the medical services market. And also in technology, legal regulations and also result from the suggestions of patients and employees. The huge role of training or benchmarking is important here. The design approach allows the organization to "deal with" complex and unique ventures. Although through the relative "ease" of launching subsequent projects, the organization may fall into an overloaded state of change. That is why it is becoming increasingly evident to master the methodology of managing multiple projects.

So, at the conceptual level, there are far-reaching analogies between project management and change management. On the other hand, differences are noticeable in the operational and executive dimensions, especially in terms of tools that can be used. It is worth emphasizing that currently interest in project management and change management focuses primarily on ensuring efficiency at the stage of selection of changes. In addition, on the selection of projects, their preparation and implementation. The search for efficiency determinants is related to the need to penetrate management subdisciplines such as risk management, quality management, human potential management (creativity) and communication management.

\section{Conclusion}

The indicated usefulness of the process approach and design approach in healthcare organizations and in developing the organization's ability to introduce changes (adaptive and innovative) encourages to shape the appropriate conditions for implementing changes. These conditions should ensure integrity in the application of approaches appropriate to individual management sub-disciplines. These subdisciplines can be understood not only as fields of theoretical knowledge, but also as a set of necessary skills. All this to effectively implement the paradigm of management of modern healthcare organizations in an extremely turbulent pandemic. There is a need to check the possibilities of using the principles, tools and solutions regarding important issues related to change, process, project. And the exchange of acquis between these management sub-disciplines.

When it comes to elements for this integration on the part of change management, it can be taken into account between the following:

- $\quad$ the concept of the change model with particular focus on the stage of change consolidation,

- dealing with the problem of reducing the efficiency of the process during a change (resulting from the so-called hole right),
- building the so-called an influential coalition for transforming resentment and resistance into employee engagement,

- developing ways of minimizing the resistance of process participants when making changes in healthcare organizations.

It seems obvious, however, that for such integration, the flow of knowledge and experience is important, which is manifested, among others, in the interest in change management and their methodology. And also knowledge of project and process management principles.

\section{Acknowledgement}

None.

\section{Conflict of Interest}

No conflict of interest.

\section{References}

1. Osbert-Pociecha G (2019) Zmiana jako meta proces $w$ organizacji procesowej, Prace Naukowe Uniwersytetu Ekonomicznego we Wrocławiu, nr 52.

2. Harasim W (2016) Paradygmaty współczesnego zarządzania organizacją, [w:] Człowiek i organizacja - dylematy współczesnego zarządzania, red. W. Harasim, Wyższa Szkoła Promocji, Warszawa.

3. Penc J (2016) Przedsiębiorstwo w burzliwym otoczeniu: procesy adaptacji i współpracy, cz. 2, Oficyna Wydawnicza OPO, Bydgoszcz.

4. Moczydłowska JM (2017) Paradygmaty zarządzania - weryfikacja w dobie kryzysu, [w:] Zrównoważony rozwój przedsiębiorstwa, red. M. Cisek i B. Domańska-Szaruga, Studio Emka, Warszawa.

5. Drucker PF (2016) Zarządzanie XXI wiekiem, Muza SA, Warszawa.

6. Jamali D (2015) Changing management paradigms: implications for educational institutions, Journal of Management Development 24(2).

7. Woźniak Sobczak B (2015) Symbioza paradygmatów zarządzania przedsiębiorstwem $\mathrm{w}$ otoczeniu sieciowym, Zeszyty Naukowe Uniwersytetu Ekonomicznego w Katowicach, Zarządzanie 2, nr 222.

8. Grudzewski WM, Hejduk IK (2018) Przedsiębiorstwo przyszłości. Zmiana paradygmatów zarządzania, Master of Business Administration, nr 1.

9. Lichtarski J (2017) Kilka refleksji o konsekwencjach przełomów w zarządzaniu i ich rozpoznawaniu, Przegląd Organizacji: 3.

10. Hamel G, Breen B (2018) Zarządzanie jutra, Red Horse Biznes, Warszawa.

11. Osbert Pociecha G (2017) Zdolność do zmian jako siła sprawcza elastyczności organizacji, Wydawnictwo Uniwersytetu Ekonomicznego we Wrocławiu, Wrocław.

12. Lichtarski J (2014) O relacjach między podejściem funkcjonalnym i procesowym w zarządzaniu, [w:] Podejście procesowe w zarządzaniu, red. M. Romanowska, Wydawnictwo SGH, Warszawa.

13. Nowosielski S (2017) Od organizacji funkcjonalnej do organizacji procesowej [w:] Procesy restrukturyzacyjne i konkurencyjność w przemyśle i usługach, red. J. Pyka, TNOiK, Katowice.

14. Grajewski P (2016) Organizacja procesowa, PWE, Warszawa.

15. Van de Ven AH, Poole MS (2015) Explaining development and change in organisations, Academy of Management Review 20(3).

16. Young M (2019) A meta model of change, Journal of Organizational Change Management 22(5).

17. Skrzypek E, Hofman M (2016) Zarządzanie procesami w przedsiębiorstwie. Identyfikowanie, pomiar, usprawnianie, Oficyna a Wolters Kluwer business, Warszawa. 
18. Paim R, Caulliraux HM, Cardoso R (2018) Process management tasks: a conceptual and practical view, Business Process Management Journal 14(5): 694

19. Daicher D (2017) The nature of project management, International Journal of Managing Projects in Business 5(4).

20. Sońta-Drączkowska E (2015) Zarządzanie wieloma projektami, PWE Warszawa.

21. Bitkowska A, Kolterman K, Wójcik G, Wójcik K (2016) Zarządzanie procesami w przedsiębiorstwie. Aspekty teoretyczno-praktyczne, Difin, Warszawa.

22. Jřrgensen F, Timenes Laugen B, Boer H (2017) Human resource management for continuous improvement. Creativity and Innovation Management 16(4).
23. Johannessen JA, Olsen B, Lumpkin GT (2017) Innovation as newness: what is new, how new, and new to whom? European Journal of Innovation Management 4(1): 20-31.

24. Lau CM, Ngo HY (2014) The HR system, organizational culture, and product innovation. International Business Review 13: 685-703.

25. Nowosielski S (2016) Orientacja procesowa w organizacjach - teoria i praktyka [w:] Metody badania i modele rozwoju organizacji, red. A. Stabryła, S. Wawak, Mlifes, Kraków.

26. Trocki M (red.) (2012) Nowoczesne zarządzanie projektami, PWE, Warszawa. 